\title{
Moving beyond the Relational Worldview: Exploring the Next Steps Premised on Agency and a Commitment to Social Change
}

\author{
Commentary on Karimi-Aghdam
}

Anna Stetsenko

The City University of New York, New York, NY, USA

\author{
Keywords \\ Vygotsky · Worldview · Transformation · Ontology · Ethics
}

I enthusiastically welcome the paper by Saeed Karimi-Aghdam [2016] for many reasons, but especially because it makes an important contribution to and serves to invigorate debates about theoretical and, more broadly, philosophical underpinnings of our contemporary approaches to human development, with crucial implications for applied fields including education. Such debates are sorely needed today as psychology continues to vacillate between the extremes of biologically deterministic views that reduce human development to processes inside the organism (and, increasingly, more narrowly inside the brain) on the one hand and those views that focus on development as a process that is distributed in and shaped by sociocultural forces without due attention to individual dynamics such as the development of the mind, self-regulation, motivation, and the self on the other. This vacillation and the accompanying painful ruptures in the approaches and disciplines concerned with human development need to be considered within the context of the "end of theory" climate - expressed for example, in the desire to deprivilege the "grand narratives" of the past - as this climate has gradually settled in psychology and other fields over several decades and even intensified in recent years. The recent dynamics are especially driven by appeals to the "evidence-based" approaches with their empirically oriented methodologies under the banner that we need to know the "facts" about development without much consideration of how these facts are enmeshed and embedded within wider theoretical and sociopolitical contexts. Alternatively, these recent dynamics are related to appeals to focus on positionality and provisionality of knowledge whereby the priority is given to localized investigations (e.g., in attunement with specific contexts and circumstances), also without much concern for theoretical and philosophical vicissitudes of knowledge production. Whether championed by mainstream ap-

\begin{tabular}{ll}
\hline KARGER & ๑ 2017 S. Karger AG, Basel \\
0018-716X/17/0595-0283\$39.50/0 \\
$\begin{array}{l}\text { E-Mail karger@karger.com } \\
\text { www.karger.com/hde }\end{array}$
\end{tabular}

Anna Stetsenko

The Graduate Center, The City University of New York 365 th Avenue

New York, NY 10016 (USA)

E-Mail astetsenko@gc.cuny.edu 
proaches with their increasing descent into biologically reductionist views, or by critical and sociocultural approaches that raise concerns over what is perceived as "master narratives" and dogmatic impositions of foundationalist discourses, the resulting picture is that of a lack of exploration into the deeply seated worldviews, philosophies, and grounding assumptions that in fact guide and underpin concrete investigations into human development. It is in this context that the paper by KarimiAghdam [2016] makes an important and timely contribution by drawing attention to how Vygotsky's cultural-historical theory (CHT) offers a unique way to conceptualize the core categories and premises of developmental theory and research.

This contribution is especially timely because it allows for more centrally positioning Vygotsky's legacy within contemporary discussions that do engage with philosophical and metatheoretical matters in thus taking exception from the programmatic atheoreticism and rote positivism in much of mainstream psychology. I agree with the message of this paper that Vygotsky has been somewhat marginalized in these discussions including those associated with Pepper's root metaphor theory. Indeed, recent important works on relational metatheory [e.g., Overton \& Mueller, 2012], philosophical implications of embodiment theories [e.g., Overton, 2004], systems perspectives including developmental [e.g., Lerner, 2004], dynamic [e.g., Thelen, 2005], and psychobiological [e.g., Lickliter \& Honeycutt, 2015] systems theories, and even dialectical models of socialization [Kuczynski \& De Mol, 2015] either do not engage with Vygotsky's theory or do so in a rather cursory way. The placement of Vygotsky within what Overton [2006] described as "the Marxist split tradition" might have played a role in sidelining CHT within the broad trend that is presently advancing dynamic, dialectical, and relational approaches. Mirroring this trend, scholars continuing to follow Vygotsky's tradition do not often engage with works related to these novel developments (exceptions include Stetsenko [2008, 2009, 2011]). The resulting lack of dialogue and collaboration among scholars interested in broad theories and worldviews that are commensurate with the complexities of human development in a multidimensional and rapidly changing world is an obstacle to developing strong alternatives to dominant atheoretical and reductionist views. These views recently amount to no less than a deeply flawed yet powerful "new grand synthesis" spanning resurrected tenets of sociobiology, innatist linguistics, narrowly conceived neuroscience, orthodox cognitivism, and the test-and-control, knowledge transmission-based educational models. It is not surprising, though highly unfortunate, that many scholars and policymakers often turn to this new grand synthesis for guidance and solutions. The answers they find are bold and speak in a unified voice - including claims to a vision of human nature that purportedly resolves all its complexities with the help of notions such as genetic endowment, natural ranking based in putatively inborn abilities, innate cognitive modules, procreation, and the mind-as-brain metaphor.

The lack of attempts to draw Vygotsky's theory into debates on metatheoretical issues has to do with difficulties in discerning the overall import of his ideas, given how they have come to be interpreted within recent Vygotskian scholarship. On the one hand, many widely acknowledged stellar breakthroughs and advancements came out of (or in association with) integrating Vygotsky's insights, through work by leading scholars of recent decades such as Jerome Bruner, Urie Bronfenbrenner, Barbara Rogoff, Michael Cole, and others. These insights reverberate and intersect with other fields including education, and communication and technology studies, with a large impact on a wide international arena. On the other hand, the philosophy at the core 
of Vygotsky's work has not been fully appreciated in contemporary interpretations, and this shortcoming has affected the way his ideas have been understood and applied [Derry, 2004; Stetsenko, 2010].

In particular, many contemporary interpretations of Vygotsky's theory focus on its fragmented (albeit important) aspects such as cultural mediation, rather than its underlying worldview. Just as with many broad systems of thought, the mistake that is often made is to understand Vygotsky's theory only after splitting it up (see the observation on Dewey's theory by Sleeper [1986]). As a result, what has passed for a discussion of Vygotky's ideas was often a series of exchanges in which misconstruals of his theory were met by refutations of each particular misconstrual, whereupon a fresh set of misconstruals took their place (in relaying Chapman's analysis of Piaget's reception, see Bickhard \& Campbell [2005]). These circumstances are exacerbated by the inherent philosophical complexity of CHT, not to mention errors in translating Vygotsky's writings, vicissitudes of his brief career (whereby he never had a chance to retrospectively assess and reflectively comment on his approach, as did Piaget and Dewey), and the fact that few researchers have the time for a systematic study of its broad corpus of ideas, philosophy, methodology, history, sociocultural context, and political-ideological ethos.

It is not surprising, although highly ironic, that Vygotsky's theory, with the worldview level assumptions left aside, is often critiqued from diametrically opposite positions. On the one hand, his approach is typically seen as placing too much emphasis on external forces, and therefore as positing development to be unidirectionally shaped by cultural and social processes. On the other hand, his approach has been critiqued for being not sufficiently social and cultural due to, as the argument goes, placing too much emphasis on independent activity of isolated individuals. For example, as Bakhurst states [2007, p. 63]: "Despite his emphasis on the sociocultural foundations of psychological development, Vygotsky's thought remains centred on the individual subject conceived as a discrete, autonomous self."

The paper by Karimi-Aghdam [2016] makes up for many gaps and disconnects in interpreting Vygotsky's theory. It draws attention to its worldview level premises and articulates them with sufficient depth and detail, and with an impressive knowledge of sources that are not familiar to most scholars in the West even though they provide an indispensable context in which to embed and further understand Vygotsky's ideas. The author's argument is that CHT has drawn upon a dialectical movement and relational epistemology to undermine the dualistic clash of contextualist (i.e., the social-historical) and organismic (i.e., the individual-biological) thinking about human development. As the paper concludes (and I share this conclusion, see Stetsenko \& Arievitch [2010]), "Vygotsky, by invoking dialectical epistemology, offers a developmental theory which eschews the pitfalls of reducing human development and consciousness to a maturation of a biological 'organism' or reducing human consciousness to an epiphenomenon of extrasomatic influences of the socialhistorical umwelt."

To reiterate, these are important and timely elaborations. Yet at the same time, in a move that builds upon these elaborations and in the spirit of Vygotsky's signal concept of the zone of proximal development, I would argue that these elaborations are confined to what can be termed a "canonical" CHT [Sawchuk \& Stetsenko, 2008]. By this I mean the import of this theory as can be deduced from its central postulates yet without inferring the direction in which its dynamics were shaping up to move 
next - on the cusp of what is established and what appears on the horizon as a result of charting the next steps. This set of dynamics operates in the spirit of exploration including self-negation that never settles and, instead, propels forward and obtains meaning precisely in this movement beyond itself. Where I think the next step can be made is in revealing how Vygotsky is implicitly drawing on values and commitments (i.e., axiological dimensions) - in particular, his passionate egalitarianism and unwavering commitment to social equality - as constitutive moments that are inherent in and inalienable from the overall fabric of his approach including its worldview and all aspects of his theory and methodology of research. Articulating such a position requires stepping beyond the bounds of a relational metatheory through a close engagement with the Marxist philosophy. Most importantly, this engagement itself needs to depart from a passive acceptance of Marxist postulates as if they were fixed and settled "once and for all," and, instead, requires critical interrogation, elaboration, and advancement in an open-ended inquiry that is prepared to move beyond what appears to be settled and stale.

A continuous critical engagement with Marxism is justified because narrow interpretations continue to persist equating the notion of materiality with economic structures and material determinations. Understood along these lines as "the Marxist split tradition," it leaves no space for elaborating complex dynamics of human development outside of impositions of sociocultural or economic determinism. Indeed, materialism in Marxist and by implication in Vygotsky's approach is predicated on the ontological centrality of material practices. Yet this position is coupled, in the works by both Marx and Vygotsky, with the political commitment to social change based on the notion that human activity is a productive force in the constitution and transformation of human development and reality itself. This broad political commitment, although not directly explicated by these scholars in terms of its ontological, epistemological, and methodological status, can and needs to be closely examined along these lines.

The core effort along these lines is to expand the premises of materialism to capitalize on human transformative agency and activism in ways that do not exclude them from the material (in the broad connotation of this term) dimensions of the world in its full historicity. In my elaboration [Stetsenko, 2016], this difficult conceptual move is possible if the material world is understood to be composed of collaborative practices extending through history and transcending the status quo, as the "world-historical activity" [Marx \& Engels, 1978, p. 163]. That is, for this position to hold, reality has to be understood in its unfolding and open-ended, dynamic historicity where the present is a continuously emergent process tied not only to previous conditions (as highlighted by many in the Marxist tradition) but also, most critically, to future conditions as these are envisioned, committed to, and acted upon by human beings qua social actors of human collaborative practices and their collective history.

The challenge to address is how to stay on the grounds of materiality and accept its primacy in engendering and shaping processes of human subjectivity and interactivity, yet, at the same time, to view these latter processes not as separate from materiality but instead, as co-implicated and instrumental in social practices in their status of agentive interventions in the course of history and the materiality of the world. This issue remains a key conundrum for critical and sociocultural scholarship, and, I believe, Vygotsky made several important steps in this direction, charting an outline for a transformative worldview that builds upon, yet also transcends the premises of the relational worldview and Pepper's root metaphor theory. 
In a powerful statement, Fredric Jameson [2006, p. xiii] wrote that he prefers "to grasp Marxism as something rather different than a philosophical system ... an as yet unnamed conceptual species one can only call a 'unity of theory and practice,' which by its very nature and structure stubbornly resists assimilation to the older philosophical 'system' as such." I believe that Vygotsky's project, too, needs to be approached as a yet unnamed approach that, in inheriting the revolutionary spirit of Marxism, moved beyond the dualistic divides between the poles of individual versus social, culture versus nature, mind versus matter, practice versus theory, among others - to instead offer a platform to grasp their dialectical unity in a peculiar blend with distinct philosophical and theoretical underpinnings. The central focus is on the nexus of people changing the world and of them being changed in the process. In this dialectically recursive and dynamically coconstitutive approach, people can be said to realize their development in the agentive enactment of changes that bring the world, and simultaneously their own development, into reality. The starting premise is that every person matters because the world is evoked, real-ized, invented, and created by each and every one of us, in each and every event of our being-knowing-doing - yet also by us as social actors and agents of communal practices and collective history, who only come about within the matrices of these practices through realizing and coauthoring them in joint struggles and strivings [see Stetsenko, 2016].

The emphasis is on the world (reality) and human development being brought into existence - that is, realized and actualized - precisely in and through the process of collaborative transformation that people instigate and carry out as actors of collective practices and agents of communal history. The dynamic and recursive, unending transitions within these continuous, bidirectional, open-ended, and coevolving circuits of social practices ceaselessly unfolding through time - as the nexus of human beings and their world at the interface of collective and individual agency and across time dimensions - are taken to be the constitutive "fabric" from which the world and human ways of being, knowing, and doing evolve and which, in the same process, they themselves bring into realization.

In this approach, the ethical dimension is rendered central to ontological, epistemological, and methodological considerations, with an activist commitment to $a$ sought-after future created and realized in the present that brings all these dimensions together as elements of a single approach. The strategy is to bridge the gap between the narrowly understood natural science and the ideological-critical orientation aimed at social transformation in the process of theory building (in overcoming the old-fashioned dualism of theory vs. practice). The intention is to construct theory closely aligned with ideology, ethics, and politics of social justice and equality and thus provide conceptual handles for possible practical interventions, including radically altering theories employed to shape education, as one step towards broad social change in respective social practices. This broad orientation not only situates $\mathrm{Vy}$ gotsky's project within the current debates on metatheory and worldviews, but also opens up ways to connect this project and these debates to critical and sociocultural approaches that are explicitly concerned with issues of social justice and social transformation such as critical pedagogy and critical race theory [e.g., Ladson-Billings \& Donnor, 2005].

There are glimpses of such an approach in Karimi-Aghdam's paper [2016]. He draws attention to the notion of praxis in several places, for example, stating that "human beings primarily come to terms with themselves and the world in and through 
practical activities." Yet bringing the full force and the radical implications of taking collaborative transformative praxis, inclusive of human agency, as the ontoepistemological grounding of human development requires more work especially in avoiding connotations of passivity, "mental reflection" (a supremely passive notion), and adaptation to the status quo of the world in its assumed "givenness." Karimi-Aghdam's focus on the interplay between natural and cultural lines of development in discussing the structure of consciousness (as in traditional interpretations of CHT; for a critique, see Arievitch \& Stetsenko [2014]) needs to be interrogated for its residual dichotomization. In its place, what might be useful is an exploration into a unified (though not uniform) realm of human development as a continuous (uninterrupted though never completed) elaboration of uniquely positioned individual contributions to collaborative historical praxis in its ongoing historicity. This approach would not eliminate insights of the relational worldview and metatheory but, instead, elevate them within a novel transformative and activist ontoepistemology that might be well suited for a world in transition in which our agency is a demand that cannot be ignored.

\section{References}

Arievitch, I.M., \& Stetsenko, A. (2014). The magic of signs: Developmental trajectory of cultural mediation. In A. Yasnitsky, R. van der Veer, \& M. Ferrari (Eds.), The Cambridge handbook of culturalhistorical psychology (pp. 217-244). New York, NY: Cambridge University Press. doi:10.1017/ CBO9781139028097.013

Bakhurst, D. (2007). Vygtsky's demons. In H. Daniels, M. Cole, \& J. Wertsch (Eds.), The Cambridge companion to Vygotsky (pp. 50-76). Cambridge: Cambridge University Press. doi:10.1017/ CCOL0521831040.003

Bickhard, M.H., \& Campbell, R.L. (2005). Editorial. New Ideas in Psychology, 23, 1-4. doi:10.1016/j.newideapsych.2005.09.002

Derry, J. (2004). The unity of intellect and will: Vygotsky and Spinoza. Educational Review, 56, 113-120. doi:10.1080/0031910410001693209

Jameson, F. (2006). Foreword. In A. Elkaim-Sartre (Ed.), Jean Paul Sartre: Critique of dialectical reason. Vol. 2 (pp. ix-xxv). London: Verso.

Karimi-Aghdam, S. (2016). Rethinking Vygotskian cultural-historical theory in light of Pepperian root metaphor theory: Dynamic interplay of organicism and contextualism. Human Development, 59, 251-282.

Kuczynski, L., \& De Mol, J. (2015). Dialectical models of socialization. In W.F. Overton, P. Molenaar, \& R.M. Lerner (Eds.), Handbook of child psychology and developmental science. Vol. 1 (7th ed., pp. 323-368). Hoboken, NJ: Wiley \& Sons. doi:10.1002/9781118963418.childpsy109

Ladson-Billings, G., \& Donnor, J. (2005). The moral activist role of critical race theory scholarship. In N.K. Denzin \& Y.S. Lincoln (Eds.), The Sage handbook of qualitative research (3rd ed., pp. 279-301). Los Angeles, CA: Sage.

Lerner, R.M. (2004). Diversity in individual-context relations as the basis for positive development across the life span: A developmental systems perspective for theory, research, and application. Research in Human Development, 1, 327-346. doi:10.1207/s15427617rhd0104_5

Lickliter, R., \& Honeycutt, H. (2015). Biology, development, and human systems. In R.M. Lerner (Ed.), Handbook of child psychology and developmental science. Vol. 1: Theory and method (pp. 162-207). New York, NY: Wiley. doi:10.1002/9781118963418.childpsy105

Marx, K., \& Engels, F. (1978). The German ideology. In R.C. Tucker (Ed.), Marx/Engels reader (2nd ed., pp. 146-200). New York, NY: Norton.

Overton, W.F. (2004). Embodied development: ending the nativism-empiricism debate. In C. Garcia Coll, E. Bearer, \& R.M. Lerner (Eds.), Nature and nurture: The complex interplay of genetic and environmental influences on human behavior and development (pp. 201-223). Mahwah, NJ: Erlbaum.

Overton, W.F. (2006). Developmental psychology: philosophy, concepts, and methodology. In R.M. Lerner (Ed.), \& W. Damon \& R.M. Lerner (Eds.-in-Chief). The handbook of child psychology. Vol. 1 (pp. 18-88). New York, NY: Wiley. 
Overton, W.F., \& Mueller, U. (2012). Metatheories, theories, and concepts in the study of development. In R.M. Lerner, M.A. Easterbrooks, \& J. Mistry (Eds.), \& I.B. Weiner (Ed.-in-Chief), Comprehensive handbook of psychology: Developmental psychology. Vol. 6 (pp. 19-58). New York, NY: Wiley.

Sawchuk, P., \& Stetsenko, A. (2008). Sociology for a non-canonical activity theory: Exploring intersections and complementarities. Mind, Culture and Activity, 15, 339-360. doi:10.1080/10749030802391427

Sleeper, R.W. (1986). The necessity of pragmatism. John Dewey's conception of philosophy. New Haven, CT: Yale University Press.

Stetsenko, A. (2008). From relational ontology to transformative activist stance: Expanding Vygotsky's (CHAT) project. Cultural Studies of Science Education, 3, 465-485.

Stetsenko, A. (2009). Vygotsky and the conceptual revolution in developmental sciences: Towards a unified (non-additive) account of human development. In M. Fleer, M. Hedegaard, J. Tudge, \& A. Prout (Eds.), World year book of education. Constructing childhood: Global-local policies and practices (pp. 125-142). New York, NY: Routledge.

Stetsenko, A. (2010). Standing on the shoulders of giants: A balancing act of dialectically theorizing conceptual understanding on the grounds of Vygotsky's project. In W.- M. Roth (Ed.), Re/structuring science education: Reuniting psychological and sociological perspectives (pp. 53-72). Dordrecht: Springer. doi:10.1007/978-90-481-3996-5_6

Stetsenko, A. (2011). Darwin and Vygotsky on development: An exegesis on human nature. In M. Kontopodis, C. Wulf, \& B. Fichtner (Eds.), Children, development and education (pp. 25-41). Dordrecht: Springer. doi:10.1007/978-94-007-0243-1_2

Stetsenko, A. (2016). The transformative mind: Expanding Vygotsky's approach to development and education. New York, NY: Cambridge University Press.

Stetsenko, A., \& Arievitch, I.M. (2010). Cultural-historical activity theory: Foundational worldview and major principles. In J. Martin \& S. Kirschner (Eds.), The sociocultural turn in psychology: The contextual emergence of mind and self (pp. 231-253). New York, NY: Columbia University Press.

Thelen, E. (2005). Dynamic systems theory and the complexity of change. Psychoanalytic Dialogues, 15 $255-283$. 